\title{
How Do Short-Term Changes at Synapses Fine-Tune Information Processing?
}

\author{
Achim Klug, ${ }^{1}$ J. Gerard G. Borst, ${ }^{2}$ Bruce A. Carlson, ${ }^{3}$ Cornelia Kopp-Scheinpflug, ${ }^{4}$ Vitaly A. Klyachko, ${ }^{5}$ \\ and Matthew A. Xu-Friedman ${ }^{6}$ \\ ${ }^{1}$ Department of Physiology and Biophysics, University of Colorado School of Medicine, Aurora, Colorado 80045, ${ }^{2}$ Department of Neuroscience, Erasmus \\ MC, University Medical Center Rotterdam, 3015 GE Rotterdam, The Netherlands, ${ }^{3}$ Department of Biology, Washington University in St. Louis, St. Louis, \\ Missouri 63130, ${ }^{4} \mathrm{MRC}$ Toxicology Unit, Leicester LE1 9HN, United Kingdom, ${ }^{5}$ Department of Cell Biology and Physiology, Washington University School of \\ Medicine, St. Louis, Missouri 63110, and ${ }^{6}$ Department of Biological Sciences, University at Buffalo, SUNY, Buffalo, New York 14260
}

Synaptic transmission is highly dependent on recent activity and can lead to depression or facilitation of synaptic strength. This phenomenon is called "short-term synaptic plasticity" and is shown at all synapses. While much work has been done to understand the mechanisms of shortterm changes in the state of synapses, short-term plasticity is often thought of as a mechanistic consequence of the design of a synapse. This review will attempt to go beyond this view and discuss how, on one hand, complex neuronal activity affects the short-term state of synapses, but also how these dynamic changes in synaptic strength affect information processing in return.

\section{Introduction}

Chemical synaptic transmission involves the physical movement of ions, molecules, and membranes as part of the signaling event, as well as during recovery from a signaling event. These mechanistic constraints limit the time scale at which synaptic transmission can function and dynamically alter the amplitudes of synaptic responses in ways that depend on recent history. Such dynamic changes, generally termed "short-term synaptic plasticity" (STP), can last from milliseconds to tens of seconds. While the mechanisms of STP are relatively well understood (Zucker and Regehr, 2002), this type of plasticity is often thought of as simply a mechanistic consequence of the design of a synapse. The functional significance of STP for information processing is much less well understood and remains controversial. On one hand, STP may serve critical roles in the processing of complex and natural streams of activity (Klyachko and Stevens, 2006; Kandaswamy et al., 2010). On the other hand, several recent studies have directly challenged the importance of STP in information processing, for example, by showing that synaptic information transmission is stochastic (Lorteije et al., 2009), or broad-band and frequency independent (Lindner et al., 2009; Yang et al., 2009). Furthermore, some synapses have been described in which EPSC amplitude is frequency independent (vestibular afferents: Bagnall et al., 2008; Purkinje cell synapses: Telgkamp et al., 2004), which raises questions about whether STP plays much of a role in

\footnotetext{
Received July 13, 2012; revised Aug. 17, 2012; accepted Aug. 20, 2012.

The work was supported by NIH Grant R01 DC11582 and DFG Grant 1842 to A.K.; NIH Grant R01 NS081972, and grants from the Fraxa Foundation and Mcdonnell Center for Systems Neuroscience grants to V.A.K; NIH Grant R01 DC008125 to M.A.X.-F.; grants from Neurobasic PharmaPhenomics (SenterNovem, The Netherlands) and HeinsiusHoubolt Fund to J.G.G.B.; NSF Grant IOS-1050701 to B.A.C.; and a MRC Career Development Fellowship in the laboratory of Prof. Ian Forsythe to C.K.-S.

Correspondence should be addressed to Achim Klug, Department of Physiology and Biophysics, University of Colorado School of Medicine, Aurora, C0 80045. E-mail: achim.klug@ucdenver.edu.

DOI:10.1523/JNEUROSCI.3348-12.2012

Copyright $\odot 2012$ the authors $\quad 0270-6474 / 12 / 3214058-06 \$ 15.00 / 0$
}

information processing at these synapses. In this review, we discuss recent findings that address the functional role of STP in a number of neural systems. The described work examines both how complex neuronal activity affects the short-term state of synapses, as well as how this changed state affects information processing in return.

\section{Hippocampus: the role of STP in regulating synaptic information transfer}

Synapses that fire continuously at high frequencies eventually reach a steady-state condition (Lindner et al., 2009, Hermann et al., 2009, Yang et al., 2009). However, many types of synapses, such as excitatory hippocampal synapses, are not likely to experience such extensive periods of high-frequency activity under natural conditions (Fenton and Muller, 1998), and therefore do not reach a steady state (Kandaswamy et al., 2010). Klyachko and Stevens (2006) have examined the information transfer across hippocampal synapses under realistic conditions and evaluated the role of STP in synaptic information transmission during natural activity (Rotman et al., 2011). They used a realistic model of STP in excitatory hippocampal synapses (Kandaswamy et al., 2010), and found that to correctly determine the influence of STP on information transfer a temporal analysis was needed in addition to rate calculations. Their results demonstrate that under more realistic conditions, STP contributes significantly to increasing information transfer in a frequency- and timedependent manner. Specifically, STP in excitatory hippocampal synapses increases information transfer in a wide range of input rates of $\sim 2-40 \mathrm{~Hz}$, which corresponds well to the naturally occurring spike frequencies in these neurons. Interestingly, timedependent information analysis predicted that in low-release probability synapses, STP acts to maximize information transfer specifically for short high-frequency bursts, which are a common firing pattern of excitatory hippocampal neurons. This prediction was confirmed by analyzing synaptic information transfer 
during natural spike trains recorded in hippocampal place cells in behaving rodents. Time-dependent information analysis further predicted that this optimization of information transfer for spike bursts depends on the presence of facilitation/augmentation and is not present in high-release probability, depressing synapses. Instead, depressing synapses are predicted to optimally transmit information for single spikes rather than bursts. Klyachko and Stevens (2006) confirmed this prediction using analysis of recordings in inhibitory hippocampal synapses that predominantly exhibit short-term depression. This result fits well with the observations that inhibitory interneurons do not commonly fire spike bursts. This study thus directly established the importance of STP in synaptic information transmission within an informationtheoretic framework, and demonstrated that STP serves to maximize information transfer for specific patterns of neural activity in both excitatory and inhibitory synapses.

\section{Hippocampus: abnormal STP in a mouse model of fragile $\mathrm{X}$ syndrome}

Klyachko and Stevens (2006) then extended the analysis of STP functions to neurodevelopmental disorders, specifically fragile $\mathrm{X}$ syndrome (FXS). FXS is the most common inherited form of intellectual disability and the leading genetic cause of autism. Despite the importance of STP in synaptic information processing, very little is known about STP dysfunctions in FXS. The limited number of studies that considered some of the STP components in Fmr1 KO mice, a widely used mouse model of FXS, came to contradictory conclusions (Centonze et al., 2008; Gibson et al., 2008; Zhang et al., 2009; Olmos-Serrano et al., 2010), and no coherent picture of STP dysfunction in FXS has emerged so far. Klyachko and Stevens (2006) revealed marked STP defects in hippocampal synapses of Fmrl KO mice (Deng et al., 2011). This altered STP resulted in abnormal synaptic computations, specifically excessive synaptic enhancement during high-frequency spike discharges associated with hippocampal place fields. Detailed analysis of individual forms of STP has shown that augmentation is strongly potentiated in Fmrl KO mice, and activityevoked calcium influx in presynaptic neurons is also increased. Moreover, short-tem depression is decreased in Fmrl KO mice, paralleled by increased size of synaptic vesicle pools and faster vesicle recycling kinetics in these animals. These results suggest that FXS is associated with abnormal STP and information processing in excitatory hippocampal synapses.

\section{Auditory nerve: converging synapses develop matched release probabilities}

A major issue concerning short-term plasticity is how it is determined at different synapses. Some synapses depress with activity, while others facilitate, depending on the probability of neurotransmitter release $\left(P_{r}\right)$ (Zucker and Regehr, 2002). When $P_{r}$ is high, activity causes depletion of releasable vesicles from the presynaptic terminal, as well as accumulation of neurotransmitter in the synaptic cleft, which can lead to postsynaptic receptor desensitization. Both of these mechanisms cause depression of EPSC amplitudes. When $P_{r}$ is low, activity does not cause significant depletion or desensitization. Rather, calcium has an opportunity to accumulate in the presynaptic terminal, and this residual calcium can cause an increase in $P_{r}$, and facilitation of EPSC amplitude. Furthermore, recovery mechanisms influence the time course of plasticity, through calcium sequestration and vesicle mobilization (Renden and von Gersdorff, 2007; Neher, 2010). Typically, a given synapse type demonstrates a consistent form and kinetics of plasticity. For example, parallel fiber synapses onto Purkinje neurons always facilitate in normal physiological saline, while climbing fiber synapses onto Purkinje neurons always depress (Perkel et al., 1990).

Remarkably, the synapses formed by a single cell onto different target neurons can show different plasticity. This phenomenon was discovered in cerebral cortex (Reyes et al., 1998) and is called "target cell-specific synaptic plasticity." This phenomenon indicates that $P_{r}$ is regulated by communication from the postsynaptic to the presynaptic neuron, although the molecular basis for this is not known.

It is also clear that there is still considerable variability in plasticity even within a uniform population of synapses made by one cell type onto another. Xu-Friedman and colleagues have investigated this issue in depth at synapses made by auditory nerve fibers onto bushy cells in the anteroventral cochlear nucleus of the mouse. These synapses, called "endbulbs of Held," consistently show depression, while auditory nerve synapses onto neighboring T-stellate cells show less depression, or even facilitation (Isaacson and Walmsley, 1996; Cao and Oertel, 2010; Chanda and Xu-Friedman, 2010). Endbulbs vary in the amount of depression they show, and dynamic-clamp experiments indicate that this has consequences for bushy cell spiking (Yang and Xu-Friedman, 2009). Increased depression reduces the likelihood that bushy cells will spike during bouts of high activity. However, it is not clear how the specific $P_{r}$ at a given endbulb is regulated, or indeed if it is precisely regulated at all. To test this, Xu-Friedman and colleagues analyzed the plasticity of distinct endbulbs converging on the same bushy cell. They found that, strikingly, these had similar plasticity (Yang and Xu-Friedman, 2009,2012 ), suggesting that plasticity is closely regulated. Further experiments with the use-dependent blocker MK-801 suggest that $P_{r}$ is similar for converging endbulbs, indicating that $P_{r}$ is somehow coordinated between them. This is a qualitatively finer scale of regulation than that accounted for by target cell-specific synaptic plasticity. Rather $P_{r}$ is regulated on a cell-by-cell basis.

The mechanisms underlying this regulation are not yet clear, but may involve activity: the similarity between converging endbulbs becomes evident shortly after the onset of hearing (Yang and Xu-Friedman, 2012). It will be interesting to establish whether activity in the auditory nerve contributes to regulating $P_{r}$, such as through processes akin to homeostatic synaptic scaling (Turrigiano, 2008).

\section{Calyx of Held and auditory brainstem: the role of STP decreases with age}

The calyx of Held synapse is a fast, glutamatergic, axosomatic relay synapse in the auditory brainstem, which is formed by fibers from globular bushy cells of the cochlear nucleus with principal neurons of the medial nucleus of the trapezoid body (MNTB) (Borst and Soria van Hoeve, 2012). Thus, in the ascending auditory system, the calyx of Held is located only one synaptic station downstream of the endbulb of Held discussed above. Each MNTB principal neuron is innervated by a single calyx. The principal neurons provide well timed inhibition to many areas in the auditory brainstem, including the sound localization nuclei. Because of the accessibility of the calyx for patch-clamp recordings in slice studies, STP has been relatively well studied in this system. These studies have provided mechanistic insights into different forms of STP, including short-term facilitation, short-term depression, and post-tetanic potentiation. More recently, the importance of STP for auditory processing was studied. An advantage of the calyx of Held synapse for in vivo recordings is that 
both presynaptic and postsynaptic signals can be recorded with a single, extracellular pipette (Guinan and Li, 1990), and that juxtacellular (loose-patch) recordings can be used to quantify both the strength of synaptic transmission and postsynaptic excitability (Lorteije et al., 2009).

Borst and colleagues have studied STP in the calyx of Held both in vitro and in vivo. Somewhat unexpectedly, they found little evidence for a dependence of the size of EPSPs on recent activity in the adult rodent calyx of Held synapse, indicating that the impact of STP is much smaller in vivo than in slice studies (Lorteije et al., 2009; Sonntag et al., 2011). Several factors are responsible for this discrepancy. One important factor is that slice studies commonly use a much higher extracellular calcium concentration than is present in vivo (Borst, 2010). As a result, the release probability will be higher in slices than in the intact brain, resulting in more synaptic depression. A second important difference is that most slice studies on STP at the calyx of Held synapse have been performed in immature animals. However, the adult synapse is much more resistant to synaptic depression, due to a lower release probability and an increase in the size of the readily releasable pool (RRP) (Taschenberger and von Gersdorff, 2000; Iwasaki and Takahashi, 2001; Taschenberger et al., 2002). Moreover, synaptic facilitation also becomes smaller after hearing onset, since both the amount of facilitation triggered per action potential becomes smaller, and its decay becomes faster (Crins et al., 2011). As a result, the impact of STP on the variability in the size of synaptic potentials is much larger before hearing onset than after (Crins et al., 2011; Sonntag et al., 2011).

Model fits of the relation between the size of synaptic potentials and recent history for in vivo recordings indicated that throughout development, synapses generally recover from synaptic depression quite slowly, with a time constant on the order of seconds (Crins et al., 2011). This is in agreement with slice studies in which recovery from modest synaptic depression was studied (von Gersdorff et al., 1997), but contrasts with the biphasic recovery observed following strong depression (Wang and Kaczmarek, 1998). An inevitable consequence of the slow recovery time constant is that the adult synapse will be to some extent tonically depressed (Hermann et al., 2007, 2009), because the spontaneous firing rates are on average $\sim 30 \mathrm{~Hz}$ in vivo (Kopp-Scheinpflug et al., 2008a), whereas the calyx of Held synapse is not spontaneously active during slice recordings.

In conclusion, three factors largely explain the apparent discrepancy in release probability between in vivo and slice recordings in the adult calyx of Held synapse, as well as the strongly reduced impact of short-term depression on the fluctuations in synaptic potentials observed in the adult calyx synapse: (1) calcium concentration and possible other differences in the extracellular solution; (2) developmental changes in release probability and RRP size; and (3) spontaneous activity in vivo. Developmental changes in the amount and decay time course of short-term synaptic facilitation are an important factor in explaining why the decrease in release probability in the adult synapse is not accompanied by a strong increase in the amount of synaptic facilitation (Crins et al., 2011). Together, these mechanisms contribute greatly to the ability of the calyx of Held synapse to deliver precise and reliable inhibition to many nuclei in the central auditory pathway at rates exceeding $300 \mathrm{~Hz}$.

\section{Calyx of Held: excitation dynamically integrates with fast inhibition}

The excitatory inputs to MNTB neurons mediated by the calyx of Held have been studied in detail and are fairly well understood (Schneggenburger and Forsythe, 2006; Kochubey et al., 2011). Much less well understood is the role of additional glycinergic inhibitory inputs to MNTB neurons. In vivo, the glycinergic inputs selectively suppress MNTB firing in response to certain sound stimuli (Kopp-Scheinpflug et al., 2008b), suggesting specific computational roles in auditory information processing. When tested in brain slices under experimental conditions lacking the chronic spontaneous background activity that is typical for auditory brainstem neurons, the inhibitory events have conductances that are approximately as large as those of the calyceal excitatory inputs and can reliably suppress MNTB firing when activated (Awatramani et al., 2004). However, auditory brainstem neurons are chronically active even in the absence of any sound due to ongoing spontaneous activity (Smith et al., 1998; Kadner et al., 2006; Hermann et al., 2007, 2009). This background activity results from auditory nerve spontaneous activity (Kiang, 1965; Liberman, 1978; Geisler et al., 1985; Hudspeth, 1997) and is one of the hallmarks of most auditory brainstem neurons. As a result, in the intact brain various mechanisms of STP are chronically active in auditory brainstem synapses, even in the absence of any sound. During the preparation of brain slices, the auditory nerves are severed and, as a result, the ongoing background activity ceases. In this unphysiologically silent environment, synapses recover from the chronic steadystate levels of STP, and exhibit different properties from the intact brain. For example, the number of releasable vesicles is reduced in active synapses or the elevated calcium levels favor faster recovery time constants from synaptic depression (Hermann et al., 2007).

Inhibitory inputs to MNTB neurons operate under levels of background activity that are similar to those of the corresponding excitatory inputs, and thus are also in a state of chronic depression and facilitation. Since the specific properties of STP in inhibitory synapses are different from those in excitatory synapses, the relative strength of excitatory inputs versus inhibitory inputs dynamically changes from moment to moment, depending on recent activity patterns. Although both excitation and inhibition have similar conductances in brain slices lacking chronic background activity (Awatramani et al., 2004), the steady-state conductances of active excitatory synapses are overall larger than the steady state of active inhibitory synapses, suggesting that the relative impact of neural inhibition during ongoing activity may be smaller than that measured in rested slices (F. M. Mayer and A. Klug, unpublished observations). However, inhibitory synapses facilitate much more prominently during stimulation with highfrequency trains than the corresponding excitatory synapses do, causing brief periods during which the computational impact of inhibition is especially high (Mayer et al., unpublished observations). Additionally, glycinergic inputs exhibit a slightly longer latency than their corresponding excitatory inputs, causing the inhibitory activity stream to lag just a moment behind the excitatory activity stream (F. M. Mayer and A. Klug, unpublished). Thus, the specific properties of excitatory and inhibitory synapses and the differential properties of STP are the basis for very complex interactions during responses to natural and ongoing neural activity patterns. 


\section{Mormyrid midbrain: synaptic filters for the processing of communication signals}

Although the mechanisms of STP influence synaptic strength in vitro, it remains a challenge to relate these processes to the processing of behaviorally relevant sensory information (Abbott and Regehr, 2004). A group of African weakly electric fishes called the Mormyridae, or elephant fishes, provides a unique opportunity for linking in vivo studies of sensory coding with in vitro studies of synaptic, cellular, and network physiology. These fishes generate all-or-none pulses of electricity, and they communicate with each other by actively varying the intervals between pulses on a time scale of tens to hundreds of milliseconds (Hopkins, 1986; Carlson, 2002; Carlson and Hopkins, 2004a,b; Arnegard and Carlson, 2005; Wong and Hopkins, 2007).

Mormyrids have an electrosensory pathway that is exclusively devoted to processing electric communication signals (XuFriedman and Hopkins, 1999). Peripheral electroreceptors respond to each stimulus pulse with a fixed latency spike, thereby directly coding the sequence of interpulse intervals into the sequence of interspike intervals (Hopkins and Bass, 1981). After filtering out responses to self-generated signals in the hindbrain (Bell and Grant, 1989), these precisely timed spikes are relayed to the midbrain, where a diverse population of neurons acts as temporal filters of interspike interval sequences, some responding selectively to short intervals, others to long intervals, and still others to intermediate intervals (Carlson, 2009). These neurons are the first ones in the sensory pathway that are tuned to interpulse intervals. Furthermore, they exhibit the same tuning to temporal patterns of sensory stimulation as they do to temporal patterns of electrical stimulation of incoming afferent fibers. Thus, the temporal filtering of spike trains arises locally within this population of neurons (Carlson, 2009). These various features of the circuit make it relatively straightforward to directly manipulate presynaptic spike timing in vivo and in vitro, and to relate temporal filtering of these inputs at synapses to the coding of behaviorally relevant sensory stimuli.

Carlson and colleagues studied the role that local inhibitory interneurons play in establishing the diversity of interval tuning observed across this population of neurons (George et al., 2011). They performed paired whole-cell recordings in vitro and revealed extensive local excitatory interactions. Differences in the relative strength and duration of excitatory and inhibitory synaptic inputs act to shape interval tuning through temporal summation, with temporally summating excitation enhancing responses to short intervals and temporally summating inhibition suppressing responses to short intervals (George et al., 2011). This basic "push-pull” mechanism can create many different types of interval tuning. In addition, paired whole-cell recordings from synaptically connected neurons in vitro as well as synaptic conductances estimated from whole-cell recordings in vivo reveal that short-term depression is ubiquitous in this circuit. Further, the relative extent of depression in excitatory and inhibitory pathways varies with respect to the interval tuning of postsynaptic neurons. Together, these findings suggest that the interplay between temporal summation and depression in excitatory and inhibitory pathways shapes the synaptic filtering of presynaptic inputs to mediate the detection of communication signals. Shortterm depression has also been implicated in frequency tuning in South American electric fish (Fortune and Rose, 2000), tuning to sound pulse rate and pulse number in frogs (Edwards et al., 2007), and motion detection in visual and electrosensory systems (Chance et al., 1998; Chacron et al., 2009), suggesting that it represents a general strategy for the temporal processing of behaviorally relevant stimuli (Fortune and Rose, 2001).

\section{Auditory brainstem: activity-dependent tuning of chloride driving force for inhibitory signaling}

The traditional mechanisms of STP described above are all geared toward regulating and dynamically altering the conductance of synapses through changes in $P_{r}$, pool size, or postsynaptic receptor open probabilities. Alternatively, synaptic current amplitudes and thereby synaptic strength can be regulated by altering the ion flow through open synaptic receptors through an alteration of the ion's driving force. There is increasing evidence for modulation of target neuron excitability (Steinert et al., 2008, 2011) or of inhibitory circuits (Chen et al., 2011) contributing to experiencedependent plasticity. Recently, Kopp-Scheinpflug et al. (2011) described a novel inhibitory mechanism underlying offsetresponses in the superior paraolivary nucleus (SPN) (Felix et al., 2011).

A powerful IPSP input from the MNTB can trigger an offset burst of action potentials through a highly negative chloride driving force combined with a fast HCN1-mediated $I_{\mathrm{h}}$ current (hyperpolarization-activated cation current). Increased synaptic activity in the MNTB releases nitric oxide (NO), a gaseous messenger molecule that is involved in the regulation of synaptic transmission and neuronal function (Garthwaite, 2008; Steinert et al., 2008, 2011). New results revealed that NO also modulates inhibitory transmission via the potassium-chloride cotransporter (KCC2) responsible for the negative chloride reversal potential $E_{\mathrm{Cl}}$ (Löhrke et al., 2005) in the SPN. Blockade of KCC2 by furosemide allows passive equilibration of chloride and shifts $E_{\mathrm{Cl}}$ toward the Nernst prediction (Kopp-Scheinpflug et al., 2011). Mimicking MNTB activity by perfusion of NO donors also causes $E_{\mathrm{Cl}}$ to shift toward more positive values, suggesting a suppression of KCC2 by NO. Despite the depolarizing shift in the IPSC reversal potential, there was no direct effect of NO signaling on IPSC conductance, neither by reducing transmitter release nor by modulation of the postsynaptic glycine receptors.

NO suppression of KCC2 is a novel finding and has broad relevance for control of inhibitory synaptic transmission in the CNS. Raising KCC2 activity shifts $E_{\mathrm{Cl}}$ to more negative voltages and thereby increases IPSP driving force, while lowering KCC2 activity had the opposite effect. Nitrergic modulation of other KCC genes by NO, such as KCC3a/b spliced genes has been described in non-nervous tissue (Di Fulvio et al., 2003). In the brain, GABA/glycinergic signaling without moderate KCC2 activity is limited to shunting the membrane conductance. The absence of KCC2 in immature states results in depolarizing synaptic responses (Rivera et al., 2005), while a reduction of KCC2 and altered $\mathrm{Cl}^{-}$homeostasis also occurs in adult models of neuropathic pain (Lu et al., 2008), ischemic brain injury (Papp et al., 2008), or after spinal cord injury (Boulenguez et al., 2010). Activity-dependent regulation of nitrergic signaling therefore provides a powerful means of regulating the strength of synaptic inhibition. For example, NO selectively tunes inhibitory synapses to modulate vertebrate locomotion by an as yet unknown mechanism (McLean and Sillar 2002). One mechanism of regulating KKC2 activity is via PP1-mediated dephosphorylation of KCC2 triggered by NMDA receptor activation (Lee et al., 2011). Our previous work has shown that in the MNTB, NMDA receptor activation leads to intracellular NO signaling, subsequently altering the balance of phosphorylation and dephosphorylation (Steinert et al., 2008). Nitrergic downregulation of KCC2 will suppress all IPSPs and will have profound effects on regulating rhythm generation throughout the CNS. 


\section{Summary}

Short-term plasticity generally refers to a number of mechanisms that dynamically alter the strength of synaptic events in response to periods of repeated activity. From a mechanistic point of view, these mechanisms are relatively well understood, but their functional roles are still unclear. In this review, we discussed recent work from several neural systems in which this plasticity has been shown to play an active role in dynamically shaping the neurons' responses to ongoing trains of activity. In the systems described, STP participates in ensuring normal functioning of its neurons, and in the enhancement, depression or filtering of certain aspects of the ascending information train. Synapse-, cell-, and activityspecific regulation of synaptic strength suggests that, at least in some of the systems described above, STP is not simply an inherent byproduct of chemical synaptic transmission, but is actively used in information processing.

\section{References}

Abbott LF, RegehrWG (2004) Synaptic computation. Nature 431:796-803. CrossRef Medline

Arnegard ME, Carlson BA (2005) Electric organ discharge patterns during group hunting by a mormyrid fish. Proc R Soc Lond B Biol Sci 272:13051314. CrossRef

Awatramani GB, Turecek R, Trussell LO (2004) Inhibitory control at a synaptic relay. J Neurosci 24:2643-2647. CrossRef Medline

Bagnall MW, McElvain LE, Faulstich M, du Lac S (2008) Frequencyindependent synaptic transmission supports a linear vestibular behavior. Neuron 60:343-352. CrossRef Medline

Bell CC, Grant K (1989) Corollary discharge inhibition and preservation of temporal information in a sensory nucleus of mormyrid electric fish. J Neurosci 9:1029-1044. Medline

Borst JGG (2010) The low synaptic release probability in vivo. Trends Neurosci 33:259-266. CrossRef Medline

Borst JGG, Soria van Hoeve J (2012) The calyx of Held synapse: from model synapse to auditory relay. Annu Rev Physiol 74:199-224. CrossRef Medline

Boulenguez P, Liabeuf S, Bos R, Bras H, Jean-Xavier C, Brocard C, Stil A, Darbon P, Cattaert D, Delpire E, Marsala M, Vinay L (2010) Downregulation of the potassium-chloride cotransporter KCC2 contributes to spasticity after spinal cord injury. Nat Med 16:302-307. CrossRef Medline

Cao XJ, Oertel D (2010) Auditory nerve fibers excite targets through synapses that vary in convergence, strength, and short-term plasticity. J Neurophysiol 104:2308-2320. CrossRef Medline

Carlson BA (2002) Electric signaling behavior and the mechanisms of electric organ discharge production in mormyrid fish. J Physiol Paris 96:405419. CrossRef Medline

Carlson BA (2009) Temporal-pattern recognition by single neurons in a sensory pathway devoted to social communication behavior. J Neurosci 29:9417-9428. CrossRef Medline

Carlson BA, Hopkins CD (2004a) Central control of electric signaling behavior in the mormyrid Brienomyrus brachyistius: segregation of behavior-specific inputs and the role of modifiable recurrent inhibition. J Exp Biol 207:1073-1084. CrossRef Medline

Carlson BA, Hopkins CD (2004b) Stereotyped temporal patterns in electrical communication. Anim Behav 68:867-878. CrossRef

Centonze D, Rossi S, Mercaldo V, Napoli I, Ciotti MT, De Chiara V, Musella A, Prosperetti C, Calabresi P, Bernardi G, Bagni C (2008) Abnormal striatal GABA transmission in the mouse model for the fragile $\mathrm{X}$ syndrome. Biol Psychiatry 63:963-973. CrossRef Medline

Chacron MJ, Toporikova N, Fortune ES (2009) Differences in the time course of short-term depression across receptive fields are correlated with directional selectivity in electrosensory neurons. J Neurophysiol 102: 3270-3279. CrossRef Medline

Chance FS, Nelson SB, Abbott LF (1998) Synaptic depression and the temporal response characteristics of V1 cells. J Neurosci 18:4785-4799. Medline

Chanda S, Xu-Friedman MA (2010) A low-affinity antagonist reveals saturation and desensitization in mature synapses in the auditory brainstem. J Neurophysiol 103:1915-1926. CrossRef Medline

Chen JL, Lin WC, Cha JW, So PT, Kubota Y, Nedivi E (2011) Structural basis for the role of inhibition in facilitating adult brain plasticity. Nat Neurosci 14:587-594. CrossRef Medline

Crins TT, Rusu SI, Rodríguez-Contreras A, Borst JGG (2011) Developmental changes in short-term plasticity at the rat calyx of Held synapse. J Neurosci 31:11706-11717. CrossRef Medline

Deng PY, Sojka D, Klyachko VA (2011) Abnormal presynaptic short-term plasticity and information processing in a mouse model of fragile $\mathrm{X}$ syndrome. J Neurosci 31:10971-10982. CrossRef Medline

Di Fulvio M, Lauf PK, Shah S, Adragna NC (2003) NONOates regulate KCl cotransporter-1 and -3 mRNA expression in vascular smooth muscle cells. Am J Physiol Heart Circ Physiol 284:H1686-H1692. Medline

Edwards CJ, Leary CJ, Rose GJ (2007) Counting on inhibition and ratedependent excitation in the auditory system. J Neurosci 27:13384-13392. CrossRef Medline

Felix RA 2nd, Fridberger A, Leijon S, Berrebi AS, Magnusson AK (2011) Sound rhythms are encoded by postinhibitory rebound spiking in the superior paraolivary nucleus. J Neurosci 31:12566-12578. CrossRef Medline

Fenton AA, Muller RU (1998) Place cell discharge is extremely variable during individual passes of the rat through the firing field. Proc Natl Acad Sci U S A 95:3182-3187. CrossRef Medline

Fortune ES, Rose GJ (2000) Short-term synaptic plasticity contributes to the temporal filtering of electrosensory information. J Neurosci 20:71227130. Medline

Fortune ES, Rose GJ (2001) Short-term synaptic plasticity as a temporal filter. Trends Neurosci 24:381-385. CrossRef Medline

Garthwaite J (2008) Concepts of neural nitric oxide-mediated transmission. Eur J Neurosci 27:2783-2802. CrossRef Medline

Geisler CD, Deng L, Greenberg SR (1985) Thresholds for primary auditory fibers using statistically defined criteria. J Acoust Soc Am 77:1102-1109. CrossRef Medline

George AA, Lyons-Warren AM, Ma X, Carlson BA (2011) A diversity of synaptic filters are created by temporal summation of excitation and inhibition. J Neurosci 31:14721-14734. CrossRef Medline

Gibson JR, Bartley AF, Hays SA, Huber KM (2008) Imbalance of neocortical excitation and inhibition and altered UP states reflect network hyperexcitability in the mouse model of fragile X syndrome. J Neurophysiol 100: 2615-2626. CrossRef Medline

Guinan JJ Jr, Li RY (1990) Signal processing in brainstem auditory neurons which receive giant endings (calyces of Held) in the medial nucleus of the trapezoid body of the cat. Hear Res 49:321-334. CrossRef Medline

Hermann J, Pecka M, von Gersdorff H, Grothe B, Klug A (2007) Synaptic transmission at the calyx of Held under in vivo-like activity levels. J Neurophysiol 98:807-820. CrossRef Medline

Hermann J, Grothe B, Klug A (2009) Modeling short-term synaptic plasticity at the calyx of Held using in vivo-like stimulation patterns. J Neurophysiol 101:20-30. CrossRef Medline

Hopkins CD (1986) Behavior of Mormyridae. In: Electroreception (Bullock TH, Heiligenberg W, eds), pp 527-576. New York: Wiley.

Hopkins CD, Bass AH (1981) Temporal coding of species recognition signals in an electric fish. Science 212:85-87. CrossRef Medline

Hudspeth AJ (1997) How hearing happens. Neuron 19:947-950. CrossRef Medline

Isaacson JS, Walmsley B (1996) Amplitude and time course of spontaneous and evoked excitatory postsynaptic currents in bushy cells of the anteroventral cochlear nucleus. J Neurophysiol 76:1566-1571. Medline

Iwasaki S, Takahashi T (2001) Developmental regulation of transmitter release at the calyx of Held in rat auditory brainstem. J Physiol 534:861-871. CrossRef Medline

Kadner A, Kulesza RJ Jr, Berrebi AS (2006) Neurons in the medial nucleus of the trapezoid body and superior paraolivary nucleus of the rat may play a role in sound duration coding. J Neurophysiol 95:1499-1508. CrossRef Medline

Kaja S, Van de Ven RC, Broos LA, Frants RR, Ferrari MD, Van den Maagdenberg AM, Plomp JJ (2010) Severe and progressive neurotransmitter release aberrations in familial hemiplegic migraine type 1 Cacna 1a S218L knock-in mice. J Neurophysiol 104:1445-1455. CrossRef Medline

Kandaswamy U, Deng PY, Stevens CF, Klyachko VA (2010) The role of presynaptic dynamics in processing of natural spike trains in hippocampal synapses. J Neurosci 30:15904-15914. CrossRef Medline

Kiang NYS (1965) Discharge patterns of single fibers in the cat's auditory nerve. Cambridge, MA: MIT 
Klyachko VA, Stevens CF (2006) Excitatory and feed-forward inhibitory hippocampal synapses work synergistically as an adaptive filter of natural spike trains. PLoS Biol 4:e207. CrossRef Medline

Kochubey O, Lou X, Schneggenburger R (2011) Regulation of transmitter release by $\mathrm{Ca}(2+)$ and synaptotagmin: insights from a large CNS synapse. Trends Neurosci 34:237-246. CrossRef Medline

Kopp-Scheinpflug C, Tolnai S, Malmierca MS, Rübsamen R (2008a) The medial nucleus of the trapezoid body: comparative physiology. Neuroscience 154:160-170. CrossRef Medline

Kopp-Scheinpflug C, Dehmel S, Tolnai S, Dietz B, Milenkovic I, Rübsamen R (2008b) Glycine-mediated changes of onset reliability at a mammalian central synapse. Neuroscience 157:432-445. CrossRef Medline

Kopp-Scheinpflug C, Tozer AJ, Robinson SW, Tempel BL, Hennig MH, Forsythe ID (2011) The sound of silence: ionic mechanisms encoding sound termination. Neuron 71:911-925. CrossRef Medline

Lee HH, Deeb TZ, Walker JA, Davies PA, Moss SJ (2011) NMDA receptor activity downregulates KCC2 resulting in depolarizing GABAA receptormediated currents. Nat Neurosci 14:736-743. CrossRef Medline

Liberman MC (1978) Auditory-nerve response from cats raised in a lownoise chamber. J Acoust Soc Am 63:442-455. CrossRef Medline

Lindner B, Gangloff D, Longtin A, Lewis JE (2009) Broadband coding with dynamic synapses. J Neurosci 29:2076-2088. CrossRef Medline

Löhrke S, Srinivasan G, Oberhofer M, Doncheva E, Friauf E (2005) Shift from depolarizing to hyperpolarizing glycine action occurs at different perinatal ages in superior olivary complex nuclei. Eur J Neurosci 22: 2708-2722. CrossRef Medline

Lorteije JA, Rusu SI, Kushmerick C, Borst JGG (2009) Reliability and precision of the mouse calyx of Held synapse. J Neurosci 29:13770-13784. CrossRef Medline

Lu Y, Zheng J, Xiong L, Zimmermann M, Yang J (2008) Spinal cord injuryinduced attenuation of GABAergic inhibition in spinal dorsal horn circuits is associated with down-regulation of the chloride transporter KCC2 in rat. J Physiol 586:5701-5715. CrossRef Medline

McLean DL, Sillar KT (2002) Nitric oxide selectively tunes inhibitory synapses to modulate vertebrate locomotion. J Neurosci 22:4175-4184. Medline

Neher E (2010) What is rate-limiting during sustained synaptic activity: Vesicle supply or the availability of release sites. Front Synaptic Neurosci 2:144. CrossRef Medline

Olmos-Serrano JL, Paluszkiewicz SM, Martin BS, Kaufmann WE, Corbin JG, Huntsman MM (2010) Defective GABAergic neurotransmission and pharmacological rescue of neuronal hyperexcitability in the amygdala in a mouse model of fragile X syndrome. J Neurosci 30:9929-9938. CrossRef Medline

Papp E, Rivera C, Kaila K, Freund TF (2008) Relationship between neuronal vulnerability and potassium-chloride cotransporter 2 immunoreactivity in hippocampus following transient forebrain ischemia. Neuroscience 154:677-689. CrossRef Medline

Perkel DJ, Hestrin S, Sah P, Nicoll RA (1990) Excitatory synaptic currents in Purkinje cells. Proc R Soc Lond B Biol Sci 241:116-121. CrossRef

Renden R, von Gersdorff H (2007) Synaptic vesicle endocytosis at a CNS nerve terminal: faster kinetics at physiological temperatures and increased endocytotic capacity during maturation. J Neurophysiol 98:3349-3359. CrossRef Medline

Reyes A, Lujan R, Rozov A, Burnashev N, Somogyi P, Sakmann B (1998) Target-cell-specific facilitation and depression in neocortical circuits. Nat Neurosci 1:279-285. CrossRef Medline

Rivera C, Voipio J, Kaila K (2005) Two developmental switches in GABAergic signalling: the $\mathrm{K}+-\mathrm{Cl}-$ cotransporter $\mathrm{KCC} 2$ and carbonic anhydrase CAVII. J Physiol 562:27-36. CrossRef Medline

Rotman Z, Deng PY, Klyachko VA (2011) Short-term plasticity optimizes synaptic information transmission. J Neurosci 31:14800-14809. CrossRef Medline

Schneggenburger R, Forsythe ID (2006) The calyx of Held. Cell Tissue Res 326:311-337. CrossRef Medline

Smith PH, Joris PX, Yin TC (1998) Anatomy and physiology of principal cells of the medial nucleus of the trapezoid body (MNTB) of the cat. J Neurophysiol 79:3127-3142. Medline

Sonntag M, Englitz B, Typlt M, Rübsamen R (2011) The calyx of Held develops adult-like dynamics and reliability by hearing onset in the mouse in vivo. J Neurosci 31:6699-6709. CrossRef Medline

Steinert JR, Kopp-Scheinpflug C, Baker C, Challiss RA, Mistry R, Haustein MD, Griffin SJ, Tong H, Graham BP, Forsythe ID (2008) Nitric oxide is a volume transmitter regulating postsynaptic excitability at a glutamatergic synapse. Neuron 60:642-656. CrossRef Medline

Steinert JR, Robinson SW, Tong H, Haustein MD, Kopp-Scheinpflug C, Forsythe ID (2011) Nitric oxide is an activity-dependent regulator of target neuron intrinsic excitability. Neuron 71:291-305. CrossRef Medline

Taschenberger H, von Gersdorff H (2000) Fine-tuning an auditory synapse for speed and fidelity: developmental changes in presynaptic waveform, EPSC kinetics, and synaptic plasticity. J Neurosci 20:9162-9173. Medline

Taschenberger H, Leão RM, Rowland KC, Spirou GA, von Gersdorff $\mathrm{H}$ (2002) Optimizing synaptic architecture and efficiency for highfrequency transmission. Neuron 36:1127-1143. CrossRef Medline

Telgkamp P, Padgett DE, Ledoux VA, Woolley CS, Raman IM (2004) Maintenance of high-frequency transmission at Purkinje to cerebellar nuclear synapses by spillover from boutons with multiple release sites. Neuron 41:113-126. CrossRef Medline

Tottene A, Pivotto F, Fellin T, Cesetti T, van den Maagdenberg AM, Pietrobon D (2005) Specific kinetic alterations of human $\mathrm{Ca}_{\mathrm{v}} 2.1$ calcium channels produced by mutation S218L causing familial hemiplegic migraine and delayed cerebral edema and coma after minor head trauma. J Biol Chem 280:17678-17686. CrossRef Medline

Turrigiano GG (2008) The self-tuning neuron: synaptic scaling of excitatory synapses. Cell 135:422-435. CrossRef Medline

von Gersdorff H, Schneggenburger R, Weis S, Neher E (1997) Presynaptic depression at a calyx synapse: the small contribution of metabotropic glutamate receptors. J Neurosci 17:8137-8146. Medline

Wang LY, Kaczmarek LK (1998) High-frequency firing helps replenish the readily releasable pool of synaptic vesicles. Nature 394:384-388. CrossRef Medline

Wong RY, Hopkins CD (2007) Electrical and behavioral courtship displays in the mormyrid fish Brienomyrus brachyistius. J Exp Biol 210:2244-2252. CrossRef Medline

Xu-Friedman MA, Hopkins CD (1999) Central mechanisms of temporal analysis in the knollenorgan pathway of mormyrid electric fish. J Exp Biol 202:1311-1318. Medline

Yang H, Xu-Friedman MA (2009) Impact of synaptic depression on spike timing at the endbulb of Held. J Neurophysiol 102:1699-1710. CrossRef Medline

Yang H, Xu-Friedman MA (2012) Emergence of coordinated plasticity in the cochlear nucleus and cerebellum. J Neurosci 32:7862-7868. CrossRef Medline

Yang Z, Hennig MH, Postlethwaite M, Forsythe ID, Graham BP (2009) Wide-band information transmission at the calyx of Held. Neural computation 21:991-1017. CrossRef Medline

Zhang J, Hou L, Klann E, Nelson DL (2009) Altered hippocampal synaptic plasticity in the FMR1 gene family knockout mouse models. J Neurophysiol 101:2572-2580. CrossRef Medline

Zucker RS, Regehr WG (2002) Short-term synaptic plasticity. Annu Rev Physiol 64:355-405. CrossRef Medline 